\title{
THE ROLE OF CANDIDATE GENES IN THE ETIOLOGY OF SCHIZOPHRENIA
}

\author{
Kieran C. Murphy and Peter McGuffin \\ Department of Psychological Medicine, University of Wales College of \\ Medicine, Heath Park, Cardiff, Wales, United Kingdom
}

There is compelling evidence from family, twin, and adoption studies for a significant genetic component to the etiology of schizophrenia. With the recent revolution in DNA technology, a more direct approach to the localization and identification of susceptibility genes is now possible.

As with other genetic diseases, the two main strategies adopted to investigate the relationship between genetic markers and schizophrenia are linkage and association studies. Linkage studies require families with multiple affected individuals and are useful in the detection of oligogenic inheritance. Conversely, association studies examine the frequency of marker alleles in unrelated affected individuals compared with healthy controls (i.e., they search for allelic association) and are generally employed in the detection of polygenic inheritance.

Studies to find linkage using genetic markers generally employ two approaches: the "positional cloning" (or "systematic search") and the "candidate gene" approaches. Positional cloning relies upon a systematic search of the entire genome for linkage using evenly spaced genetic markers. Alternatively, in the candidate gene approach, cloned genes that plausibly may be involved in the pathogenesis of schizophrenia are targeted. As the present genetic map is not yet sufficiently detailed to allow a systematic search for association, studies to detect allelic association generally adopt the candidate gene approach.

In this review, we shall examine the current candidate genes implicated in the etiology of schizophrenia. In addition, we shall describe a candidate mechanism which may help to explain

Address correspondence and reprint requests to: Kieran C. Murphy, Department of Psychological Medicine, University of Wales College of Medicine, Heath Park, Cardiff, CF4 4XN, Wales, United Kingdom. the complex non-Mendelian patterns of transmission observed in multiply affected families.

\section{DOPAMINE RECEPTORS}

Disturbances in dopamine neurotransmission have been implicated in the pathogenesis of schizophrenia, primarily on the basis of two observations. First, dopaminergic agonists such as amphetamine can induce a psychosis which mimics schizophrenia and, second, antipsychotic drugs are dopamine receptor antagonists.

Five dopamine receptors have been isolated and each has been considered a target for the candidate gene strategy. Linkage studies of the dopamine D1 (1), dopamine D2 (2), and dopamine D4 (3) receptor genes have all been essentially negative. The dopamine $\mathrm{D} 3$ receptor gene (DRD3) has recently become the focus of particular interest in schizophrenia as it is the target for both typical and the newer atypical antipsychotics. It is also localized to limbic brain structures which have been implicated in the pathogenesis of schizophrenia. Attention has also been directed to the DRD3 by reports that DRD3 rather than DRD2 is up-regulated by both typical and atypical antipsychotics $(4,5)$.

Considerable excitement was generated when Lannfelt and colleagues (6) detected a point mutation within exon 1 of DRD3 giving rise to a glycine to serine substitution and creating a $B a l$ I restriction enzyme site. Although no evidence for linkage has been found between schizophrenia and this polymorphism (7), groups in France and the United Kingdom independently found homozygosity in schizophrenic patients $(p=0.005$ in the U.K. sample; $p=0.008$ in the French sample) (8).

Family-based association studies have 
proved particularly useful in detecting genes involved in complex disorders, especially when adopting a candidate gene approach (9). In contrast to other association studies, the problem of sample stratification does not occur, as parents are used as their offspring's controls. Utilizing this approach, a large collaborative study involving 11 centers has recently succeeded in replicating this association between highly familial schizophrenia and excess homozygosity at the D3 receptor gene (J. Williams et al., submitted).

How can this finding of excess homozygosity be explained in terms of increased susceptibility to schizophrenia? One possibility is that (apparent) excess homozygosity may in fact reflect the presence of a microdeletion of one copy of a DRD3 allele. However, allele loss was not reported by Williams and colleagues (J. Williams et al., submitted) or in previous family studies (10). Another possibility is that this is an example of heterosis, where heterozygosity at DRD3 confers protection against schizophrenia. A third possibility is that this polymorphism may not itself be of functional significance but may be in linkage disequilibrium with another genetic variant that is. To examine this possibility, Asherson and colleagues (11) recently screened all six exons of DRD3 using single-stranded conformational polymorphism analysis (SSCP). Their findings suggested that the DRD3 gene was highly conserved, as no other mutations were found that altered protein structure. However, they suggested that other coding region polymorphisms may occur in other regions such as the promoter region.

Several studies have failed to demonstrate linkage between the dopamine D5 receptor and schizophrenia (12-14). Recently however, Williams and colleagues (N. M. Williams et al., submitted) have reported an association between a polymorphism at the dopamine $\mathrm{D} 5$ receptor gene and schizophrenia. If this association is confirmed in other samples, the absence of positive linkage findings suggests that this susceptibility locus at DRD5 confers only a modest increased risk of schizophrenia.

\section{CATECHOL-O- METHYLTRANSFERASE}

As catechol-O-methyltransferase (COMT) catalyzes the $O$-methylation of cathecholamine neurotransmitters (dopamine, adrenaline, and nor- adrenaline), thereby inactivating them, the gene coding for COMT has been proposed as a possible candidate gene for schizophrenia. Further evidence for a possible role of the COMT gene in schizophrenia comes from the observation that the gene coding COMT maps to that region of chromosome $22 \mathrm{ql} 1$ deleted in velo-cardio-facial syndrome (VCFS) $(15,16)$. This is of particular interest because VCFS is associated with a higher than normal prevalence of psychosis (17), which is often schizophrenic in nature (18).

Several early studies have reported that COMT activity was significantly higher in patients with schizophrenia than in controls (1922 ), although several subsequent studies have not succeeded in replicating these results (2327). In a recent study, however, Daniels and colleagues (28) found no evidence for allelic association between schizophrenia and a polymorphism determining high or low catechol-Omethyltransferase activity. The power to detect genes of minor effect was low in this study, however, and the study requires replication using a larger sample size.

\section{5-HT 2A $_{\text {RECEPTOR }}$}

Genes involved in serotonergic neurotransmission have recently become the focus of considerable attention for several reasons. First, lysergic diethylamide (LSD), which has a similar molecular structure to serotonin (5-HT), is known to produce psychosis in healthy subjects (29). Second, there are relatively consistent findings of altered 5-HT receptor densities and 5-HT metabolism in the brains of patients with schizophrenia (30). Third, Arranz and colleagues (31) have reported an association between a favorable response to Clozapine (an atypical antipsychotic drug with a high affinity for serotonin receptors) and a polymorphism of the $5-\mathrm{HT}_{2 \mathrm{~A}}$ receptor gene.

The $5-\mathrm{HT}_{2 \mathrm{~A}}$ receptor gene and the surrounding region of chromosome 13 had been effectively excluded as a candidate locus for schizophrenia by a previous linkage study (32). However, in a large European association study, Williams and colleagues (33) have recently reported that individuals heterozygous or homozygous for the $\mathrm{T} 102 \mathrm{C}$ polymorphism of the $5-\mathrm{HT}_{2 \mathrm{~A}}$ receptor gene were at increased risk of schizophrenia. Although the odds ratio is small (1.7), the attributable fraction is large $(0.35)$ as the variant is common. Interestingly, this association 
has also been replicated in an ethnically distinct population, although in that study the effect was more striking for T102C homozygotes (34).

Several subsequent studies (using much smaller sample sizes) have failed to replicate this association between $\mathrm{T} 102 \mathrm{C}$ and schizophrenia (35-38). However, we have combined data from these studies with the data of Williams and colleagues (33) by means of Woolf's analysis (39). This method allows data from different populations to be combined and provides a means of testing for heterogeneity. The analysis showed that the overall association between schizophrenia and T102C remains significant $(p=0.0008$, one-tailed; odds ratio 1.18 [95\% confidence interval 0.07-1.32]) (J. Williams, submitted).

How might the $5-\mathrm{HT}_{2 \mathrm{~A}}$ receptor gene and its allelic variant contribute to an increased susceptibility to schizophrenia? As the polymorphism does not alter the amino acid composition of the receptor, it is unlikely that the variant itself is directly causal. One possibility is that the T102C polymorphism may affect the stability or translation of $5-\mathrm{HT}_{2 \mathrm{~A}}$ mRNA and alter the abundance of the expressed receptor (31). However, Burnett and Harrision (40) were unable to show any relationship between the $\mathrm{T} 102 \mathrm{C}$ genotype and receptor abundance.

Another possibility is that this polymorphism is in linkage disequilibrium with another polymorphism in the $5-\mathrm{HT}_{2 \mathrm{~A}}$ receptor gene. Mutational analysis of the entire coding region for the $5-\mathrm{HT}_{2 \mathrm{~A}}$ receptor gene has detected two coding polymorphisms (Thr25Asn and His452Tyr) (41). However, neither polymorphism showed an allelic association with schizophrenia within a population that showed an association with the T102C polymorphism. It remains a possibility, however, that other polymorphisms may exist in the promoter, in other regulatory regions of the $5-\mathrm{HT}_{2 \mathrm{~A}}$ receptor gene, or indeed in neighboring genes.

\section{CANDIDATE MECHANISMS OF TRANSMISSION}

Complex, non-Mendelian patterns of transmission in schizophrenia may be due to a variety of mechanisms including genomic imprinting and dynamic mutations. Recent studies have supported the view that anticipation occurs in multiplex families transmitting schizophrenia (4244) and are consistent with the possible genetic transmission of schizophrenia through trinucleotide repeat expansion.

Recently, O'Donovan and colleagues (45), using the repeat expansion detection (RED) method to detect the presence (although not the location) of expanded repeats, demonstrated a significant shift towards larger CAG/CTG repeats in schizophrenic (and bipolar) probands compared with controls. Similar findings have been independently reported (46) and further replicated in a European multicenter study (47). Cardno and colleagues (48) examined the relationship between such expansions and specific subsyndromes or clinical features of schizophrenia but were unable to find any correlation between them.

In an attempt to identify the specific expanded CAG/CTG locus or loci associated with schizophrenia, Bowen and colleagues (49) adopted an approach using RED and a CAG/CTG polymerase chain reaction (PCR) screening set. They were unable to identify specific loci associated with schizophrenia and have so far excluded 50 loci from the screening set as candidates for expansion in schizophrenia.

\section{CONCLUSIONS}

Evidence for a significant genetic contribution to the etiology of schizophrenia has led to a surge of molecular genetic research into the etiology of schizophrenia. Recent candidate gene studies suggest that polymorphisms at the dopamine D3 receptor gene and the $5-\mathrm{HT}_{2 \mathrm{~A}}$ receptor gene confer susceptibility to schizophrenia. In addition, the replicated findings of expanded trinucleotide repeats in schizophrenia suggest a possible mechanism to explain the complex and non-Mendelian patterns of transmission. There is considerable excitement that the large collaborative studies currently underway promise to identify more genes of both major and minor effects over the next number of years.

\section{ACKNOWLEDGMENTS}

We are grateful to the Medical Research Council (United Kingdom) for support via a Programme Grant. KM is an MRC Training Fellow. 


\section{REFERENCES}

1. Wildenaur DB, Schwab S, Wurl D, et al. (1991) Linkage analysis in schizophrenia, exclusion of 5q11-q13, 5q34-qter, 1 lq22, 23. Xpter and chrokmosome 19 in 15 systematically ascertained European families. Am. J. Hum. Genet. 49(Suppl): 363.

2. Moises HW, Gelertner J, Giuffra L, et al. (1991) No linkage between D2 dopamine receptor gene region and schizophrenia. Arch. Gen. Psychiatry 48: 643-647.

3. Shaikh S, Gill M, Owen M, et al. Failure to find linkage between a functional polymorphism in the dopamine D4 receptor gene and schizophrenia. Am. J. Med. Genet. (Neuropsych. Genet.) 54: 8-11.

4. Buckland PR, O'Donovan M, McGuffin P. (1992) Changes in dopamine D1, D2 and D3 receptor mRNA levels in rat brain following antipsychotic treatment. Psychopharmacology (Berl) 106: 479-483.

5. Buckland $P R, O^{\prime}$ Donovan $M C$, McGuffin $P$. (1993) Clozapine and sulpiride up-regulate dopamine D3 receptor mRNA levels. Neuropharmacology 32: 901-907.

6. Lannfelt L, Sokoloff $\mathrm{P}$, Martres M, et al. (1992) Amino-acid substitution in the dopamine D3 receptor as a useful polymorphism for investigating psychiatric disorders. Psychiatr. Genet. 2: 249-256.

7. Coon H, Byerley W, Holik J, et al. (1993) Linkage analysis between schizophrenia and 5 dopamine receptors. Am. J. Hum. Genet. 52: 327-334.

8. Crocq M-A, Mant $\mathrm{R}$, Asherson $\mathrm{P}$, et al. (1992) Association between schizophrenia and homozygosity at the dopamine D3 receptor gene. J. Med. Genet. 29: 858-860.

9. Schaid DJ, Sommer SS. (1994) Comparison of statistics for candidate-gene association studies using cases and parents. Am. J. Hum. Genet. 55: 402-409.

10. Mant R, Williams J, Asherson P, et al. (1994) Relationship between homozygosity at the dopamine D3 receptor gene and schizophrenia. Am. J. Med. Genet. 54: 21-26.

11. Asherson P, Mant R, Holmans P, et al. (1996) Linkage, association and mutational analysis of the dopamine D3 receptor gene in schizophrenia. Mol. Psych. 1: 125-132.

12. Ravindranathan $\mathrm{A}$, Coon $\mathrm{H}$, DeLisi $\mathrm{L}$, et al. (1994) Linkage analysis between schizophrenia and a microsatellite polymorphism for the D5 dopamine receptor gene. Psychiatr. Genet. 4: 77-80.

13. Asherson P, Mant R, Owen M. (1995) A linkage study of the dopamine $\mathrm{D} 5$ receptor and schizophrenia. Psychiatr. Genet. 5: 46.

14. Kalsi G, Sherrington R, Mankoo BS, et al. (1996) Linkage study of the D5 dopamine receptor gene (DRD5) in multiplex Icelandic and English schizophrenia pedigrees. Am. J. Psych. 153: 107-109.

15. Scambler PJ, Kelly D, Lindsay E, et al. (1992) Velo-cardio-facial syndrome associated with chromosome 22q11 deletions encompassing the DiGeorge locus. Lancet 339: 1138-1139.

16. Kelly D, Goldberg R, Wilson D, et al. (1993) Confirmation that the velo-cardio-facial syndrome is associated with haplo-insufficiency of genes at chromosome 22q11. Am. J. Med. Genet. 45: 308-312.

17. Shprintzen RJ, Goldberg R, Golding-Kushner KJ, et al. (1992) Late-onset psychosis in the velo-cardio-facial syndrome. Am. J. Med. Genet. 42: 141-142.

18. Pulver AE, Nastadt G, Goldberg R, et al. (1994) Psychotic illness in patients diagnosed with velo-cardio-facial syndrome and their relatives. J. Nerv. Ment. Dis. 182: 476478.

19. Matthysse S, Baldessarini RJ. (1972) Sadenosylmethionine and catechol-O-methyltransferase in schizophrenia. Am. J. Psych. 128: $1310-1312$.

20. Shopsin B, Wilk S, Gershon S, et al. (1973) Collaborative psychopharmacological studies exploring catecholamine metabolism in psychiatric disorders. In: Usdin E, Snyder S(eds) Frontiers in Catecholamine Research. Pergamon Press, New York, pp. 1173-1179.

21. Poitou P, Assicot M, Bouhon C. (1974) Soluble and membrane catechol-O-methyltransferases in red blood cells of schizophrenic patients. Biomedicine 21: 91-93.

22. White HL, McLeod MN, Davidson JRT. (1976) Catechol-O-methyltransferase in red blood cells of schizophrenic, depressed and normal human subjects. Br. J. Psych. 128: 184-187.

23. Floderus Y, Ross SB, Wetterburg L. (1981) Erythrocyte catechol-O-methyltransferase activity in a Swedish population. Clin. Genet. 19: 389-392.

24. Dunlop SR, Sattin A, Shea P, et al. (1981) Comparison of MAO, D beta $\mathrm{H}$, and COMT activities in chronic schizophrenics selected 
on the basis of nailfold capillary pattern. Acta. Psychiatr. Scand. 64: 409-414.

25. Lewander $T$, Von Pongracz $G$, Backstrom $M$, et al. (1981) Dopamine metabolism in red blood cells in schizophrenia. Clin. Genet. 19: 410-413.

26. Baron $M$, Gruen R, Levitt $M$, et al. (1984) Erythrocyte catecholamine-O-methyltransferase activity in schizophrenia: Analysis of family data. Am. J. Psych. 141: 29-32.

27. Eberhard G, Ross S, Saaf J, et al. (1989) Psychoses in twins. A 10 year clinical and biochemical follow-up study. Schiz. Res. 2: 367-374.

28. Daniels JK, Williams NM, Williams J, et al. (1996) No evidence for allelic association between schizophrenia and a polymorphism determining high or low catechol-O-methyltransferase activity. Am. J. Psych. 153: 268270.

29. Gaddum JH. (1954) Drugs antagonistic to 5-hydroxytryptamine. In: Wolstenholme GW (ed). Ciba Foundation Symposium on $\mathrm{Hy}$ pertension. Little, Brown, Boston, pp. 75-77.

30. Roth BL, Meltzer HY. (1995) The role of serotonin in schizophrenia. In: Bloom FE, Kupfer DJ (eds). Psychopharmacology: The Fourth Generation of Progress. Raven Press, New York, pp. 1215-1228.

31. Arranz M, Collier D, Sodhi M, et al. (1995) Association between clozapine response and allelic variation in $5-\mathrm{HT}_{2 \mathrm{~A}}$ receptor genes. Lancet 346: 281-282.

32. Hallmayer J, Kennedy JL, Wetterberg L, et al. (1992) Exclusion of linkage between the serotonin 2 receptor and schizophrenia in a large Swedish kindred. Arch. Gen. Psych. 49: 216-219.

33. Williams J, Spurlock G, McGuffin, et al. (1996) Association between schizophrenia and the $5-\mathrm{HT}_{2 \mathrm{~A}}$ receptor gene in a large European sample. Lancet 347: 1294-1296.

34. Inayama Y, Yoneda H, Ishida T, et al. (1994) An association between schizophrenia and a serotonin receptor DNA marker (5HTR2). Neuropsychopharmacology 10: 56s.

35. Malhotra AK, Goldman D, Buchanan R, et al. (1996) $5-\mathrm{HT}_{2 \mathrm{~A}}$ receptor polymorphism and schizophrenia. Lancet 347: 1830-1831.

36. Jonsson E, Nothen MM, Bunzel $R$, et al. (1996) $5 \mathrm{HT}_{2 \mathrm{~A}}$ receptor polymorphism and schizophrenia. Lancet 347: 1831.
37. Arranz MJ, Lin M-W, Powell J, et al. (1996) $5 \mathrm{HT}_{2 \mathrm{~A}}$ receptor polymorphism and schizophrenia. Lancet 347: 1831-1832.

38. Sasaki T, Hattori M, Fukuda R, et al. (1996) $5 \mathrm{HT}_{2 \mathrm{~A}}$ receptor polymorphism and schizophrenia. Lancet 347: 1832.

39. Woolf B. (1955) On estimating the relation between blood groups and disease. Ann. Hum. Genet. 19: 251-253.

40. Burnett PWJ, Harrison PJ. (1995) Genetic variation in the $5-\mathrm{HT}_{2 \mathrm{~A}}$ receptor and response to clozapine. Lancet 346: 909.

41. Nothen MM, Rietschel M, Erdmann J, et al. (1995) Genetic variation of the $5-\mathrm{HT}_{2 \mathrm{~A}}$ receptor and response to clozapine. Lancet 346: 908-909.

42. Asherson $\mathrm{P}$, Walsh $\mathrm{C}$, Williams $\mathrm{J}$, et al. (1994) Imprinting and anticipation-Are they relevant to genetic studies of schizophrenia? Br. J. Psych. 164: 619-624.

43. Bassett AS, Honer WG. (1994) Evidence for anticipation in schizophrenia. Am. J. Hum. Genet. 54: 864-870.

44. Thibaut F, Martinez M, Petit M, et al. (1995) Further evidence for anticipation in schiziophrenia. Psych. Res. 59: 25-33.

45. O'Donovan MC, Guy C, Craddock N, et al. (1995) Expanded CAG repeats in schizophrenia and bipolar disorder. Nat. Genet. 10: 380-381.

46. Morris AG, Gaitonde E, McKenna PJ, et al. (1995) CAG repeat expansions and schizophrenia: Association with disease in females and with early age-at-onset. Hum. Mol. Genet. 4: 1957-1961.

47. O'Donovan MC, Guy C, Craddock N, et al. (in press) Confirmation of association between expanded CAG/CTG repeats and both schizophrenia and bipolar disorder. Psychol. Med.

48. Cardno AG, Murphy KC, Jones LA, et al. (1996) Expanded CAG/CTG repeats in schizophrenia: A study of clinical correlates. Br. J. Psych. 169(6): 766-771.

49. Bowen T, Guy C, Speight G, et al. (1996) Expansion of 50 CAG/CTG repeats excluded in schizophrenia by application of a highly efficient approach using RED and a PCR screening set. Am. J. Hum. Genet. 59: 912917. 